\title{
PERLINDUNGAN HUKUM TERHADAP KEAMANAN DATA PRIBADI KONSUMEN TEKNOLOGI FINANSIAL DALAM TRANSAKSI ELEKTRONIK
}

\author{
A.A. Ngurah Deddy Hendra Kesuma, I Nyoman Putu Budiartha \& Putu Ayu Sriasih Wesna \\ Fakultas Ilmu Hukum, Universitas Warmadewa, Denpasar-Bali, Indonesia \\ agungngurahdeddy@gmail.com, budiartha59@gmail.com \& ayuwesna@gmail.com
}

\begin{abstract}
Abstrak
Perkembangan industri digital saat ini, penggunaan data pribadi semakin meningkat. Seseorang dengan mudah menyerahkan data pribadi ke aplikasi online, seperti Teknologi Finansial dan transaksi online, sebagai syarat agar dapat memakai layanan tersebut. Namun pemakaian data pribadi dapat beresiko bocor, serta dapat merugikan masyarakat. Penelitian ini bertujuan untuk membahas perlindungan hukum terhadap data pribadi konsumen Teknologi Finansial, dan upaya hukum yang dapat dilakukan oleh konsumen Teknologi Finansial jika data pribadi disalahgunakan oleh penyelenggara. Metode penelitian ini penelitian normatif. Pendekatan masalah tersebut yaitu pendekatan perundang-undangan dan pendekatan konseptual. Hasil penelitian menunjukkan data pribadi tern yata merupakan data yang mengungkapkan identitas diri, kode, lambang, huruf atau angka untuk menandakan seseorang yang bersifat pribadi, apabila terjadi perselisihan dan konsumen mengalami kerugian, maka korban penyalahgunaan data pribadi dapat mengambil tindakan hukum dengan meninjau dan mengadu ke Kominfo atau OJK (non litigasi). Jika tidak ada tanggapan, sengketa konsumen dapat mengajukan gugatan perdata (litigasi) I $\mathrm{PMH}$ dan menuntut ganti rugi berdasarkan perbuatan melawan hukum.
\end{abstract}

Kata kunci: Data Pribadi, Perlindungan Hukum, Teknologi Finansial, Transaksi Eletronik.

\begin{abstract}
These days, the utilize of personal data is progressively gigantic in line with the current improvement of the digital industry, the publics submit their data to online applications such as Financial Technology and online trading as a necessity of being able to utilize these services. The purposes of this research are to discuss the Legal protection against the personal data of Financial Technology consumers and the legal remedies can Financial Technology consumers take if the personal data is abused by the organizer. The results showed that personal data is information within the frame of identities, codes, symbols, letters, or numbers that demonstrate a person's individual identity. In the event that within the future there is a dispute and the consumer endures a misfortune, the casualty of personal data abuse can take legal action by way of deliberation and complaints to the Ministry of Communication and Information or OJK (non-litigation) and if it does 1101 resolve consumer disputes, they can record a gracious suit (litigation) 011 the premise of illegal acts IP M Hand ask for emolument.
\end{abstract}

Keywords: Electronic transaction, Financial Technology, Legal Protection, Personal Data,

\section{PENDAhuluan}

Perlindungan hukum adalah salah satu metode yang sangat banyak dilakukan untuk melindungi subjek hukum dari kesewenang-wenangan. Kegiatan usaha merupakan salah satu yang mendapatkan perlindungan hukum. Penting untuk memberikan perlindungan hukum untuk memastikan bahwa usaha yang dijalankan dilindungi dan terus berjalan dengan lancar (Tongat, 2008: 21-22). Salah satu contoh munculnya tren di era digitalisasi disampaikan oleh Kementerian Komunikasi dan lnformatika Republik Indonesia bahwa masyarakat tak sekedar mencari informasi atau chatting dengan menggunakan gawai. Perilaku konsumtif dari sebagian masyarakat menjadi alasan mengapa e-commerce yang akhimya menjadi alah satu bagian dari definisi Teknologi Finansial (Fintech) di Indonesia terus berkembang. Peningkatan pengguna Teknologi Finansial ini tidak luput dari berbagai macam manfaat yang diberikan untuk mempermudah dan membuat kegiatan masyarakat menjadi jauh lebih efektif. Pesatnya pertumbuhan perusahaan teknologi finansial juga tidak terlepas dari berbagai jasa keuangan yang 
disediakan oleh teknologi finansial, yang sangat membantu masyarakat khususnya di bidang keuangan untuk lebih efektif dalam menjalankan roda perekonomian. (Margaretha, 2015: 516) Namun, fakta membuktikan bahwa dalam proses implementasi, bisnis teknologi finansial memiliki potensi risiko, paling tidak ada 2 potensi risiko, yaitu risiko keamanan data pribadi konsumen dan risiko kesalahan transaksi. (OJK) Kedua risiko ini akan merugikan setiap pihak yang berkecimpung di bisnis teknologi finansial.

Perilaku kriminal seperti penyadapan, pencurian, dan cybercrime dalam transaksi keuangan perbankan membuat masyarakat enggan melakukan transaksi secara online (Chrismastianto, 2017: 148). Risiko tersebut tidak dapat dianggap remeh karena terkait dengan data pribadi konsumen, yaitu harus ada tindakan tegas yang dalam sebuah perlindungan hukum. Dengan adanya peningkatan perkembangan Teknologi Finansial ini, maka Pemerintah Indonesia dihadapkan pada risiko-risiko ancaman yang berpotensi terjadi melalui teknologi ini, termasuk risiko ancaman terhadap keamanan data konsumen. Data konsumen yang diberikan melalui Teknologi Finansial akan masuk ke dalam sistem internet dan rentan tentang penyelewengan data, dengan cara sengaja ataupun tidak sengaja, seperti oleh hacker, malware, atau penyedia layanan Teknologi Finansial itu sendiri. (Ansori, 2019: 39). Data konsumen merupakan privasi individu yang seharusnya dilindungi dan digunakan untuk kepentingan pendataan. Penyalahgunaan data konsumen ini tentu merugikan konsumen karena digunakan untuk kepentingan lain yang menguntungkan pelaku serta ketidaksesuaian terhadap hukum yang ada di Indonesia. Selain itu, ditemukan juga beberapa fenomena penjualan data konsumen yang dilakukan secara daring, termasuk melalui deep web. Data pribadi konsumen tersebut dijual karena penjualan data secara ilegal ini telah menjadi salah satu bisnis yang memiliki cukup banyak peminat. Data konsumen yang seharusnya menjadi perhatian lebih dalam keamanan di era Teknologi Finansial justru menjadi aset jual beli yang diperdagangkan bagi oknum yang tidak bertanggung jawab.

Penelitian ini dilakukan berfokus pada risiko mengenai keamanan suatu data pribadi bagi konsumen dalam bidang bisnis Teknologi Finansial di Indonesia. Perlindungan data pribadi konsumen Teknologi Finansial sepenuhnya dibutuhkan, dan wajib terdapat beberapa regulasi untuk memastikan rahasia data pribadi pada konsumen dalam ranah bisnis Teknologi Finansial. Ini karena data pribadi konsumen dibanjiri dan dapat disebarkan serta menjadi produk yang dijual secara ilegal. Dengan adanya aturan yang menjamin kerahasiaan data pribadi konsumen, maka masyarakat akan merasa jauh lebih aman dalam melakukan kegiatan dan transaksi yang dilakukan dengan menggunakan Teknologi Finansial. Perlindungan terhadap data pribadi konsumen di dalam Teknologi Finansial harus dilakukan dengan menggunakan aturan-aturan yang dikeluarkan oleh pemerintah. Selain iru, pihak penyedia layanan Teknologi Finansial juga memiliki kewajiban untuk menjaga ketersediaan, rahasia dan keutuhan, dari data keuangan, data jual beli, serta data pribadi pada konsumen mereka, dimulai dari awal pendaftaran hingga penghapusan data tersebut. Apabila penyedia layanan Teknologi Finansial berencana untuk menggunakan data-data tersebut, maka mereka harus mendapatkan persetujuan dari konsumen dengan menjelaskan batasan- batasan pemanfaatan data dengan rinci, termasuk tujuan dan informasi penggunaan data tersebut. Jika penyedia layanan Teknologi Finansial tidak dapat melindungi data konsumen hingga terjadi kebocoran, maka akan diberikan sanksi sesuai dengan regulasi pada Peraturan Menteri Kominfo Republik Indonesia dan POJK. (Benuf dkk 2019: 145-160).

Ada beberapa penelitian terdahulu yang relevan dengan penelitian saat ini. (Mahmudah \& Priyono, 2019). Penelitian ini bertujuan untuk mengetahui perlindungan hukum terhadap keamanan data konsumen dalam bisnis Fintech di Indonesia, berdasarkan Peraturan Otoritas Jasa Keuangan, dan peraturan terkait. Dalam penelitian (Pratama dkk, 2016) membahas mengenai perlindungan hukum terhadap data pribadi pengguna jasa transportasi online dari tindakan penyalahgunaan pihak penyedia jasa berdasarkan Undang-Undang Nomor 8 Tahun 1999 tentang perlindungan konsumen. Peneliti kemudian memutuskan untuk menganalisa perlindungan hukum terhadap keamanan data pribadi konsumen teknologi finansial dalam transaksi elektronik. Penelitian ini bertujuan untuk membahas perlindungan hukum terhadap data pribadi konsumen Teknologi Finansial, dan upaya hukum yang dapat dilakukan oleh konsumen Teknologi Finansial jika data pribadi disalahgunakan oleh penyelenggara.

\section{METODE PENELITIAN}

Penelitian yang digunakan adalah jenis penelitian berupa hukum normatif. Penelitian ini menggunakan metode penelitian normatif dimana penelitian ini berpatokan pada peraturan pemerintah (Darmawan 
dkk, 2021). Penelitian ini menggunakan pendekatan perundangan-undangan dan pendektan konseptual. Bahan hukum yang digunakan dalam penelitian hukum normatif yaitu bahan hukum primer serta bahan hukum sekunder. Bahan hukum primer dalam penelitian ini yaitu Undang-Undang Dasar Negara Republik Indonesia serta Peraturan Otoritas Jasa Keuangan, sedangkan perolehan bahan hukum sekundernya berasal dari buku-buku literatur artikel, makalah, serta internet (Puryanto dkk, 2021).

\section{PEMBAHASAN}

\section{Perlindungan hukum terhadap data pribadi konsumen Teknologi Finansial}

Perlindungan hukum merupakan bentuk perlindungan mengenai Hak Asasi Manusia yang dapat membuat kerugian bagi masyarakat lainnya, serta perlindungan ditujukan ke seluruh elemen masyarakat untuk memberikankebebasan keseluruhan hak yang diatur oleh regulasi yang ada. Yang dimaksudkan, perlindungan hukum yaitu beberapa tindakan yang bersifat hukum wajib diperoleh oleh aparat penegak hukum. Fungsi apparat sendiri adalah dapat memberikan rasa aman kepada masyarakat. Menurut Philipus M. Hadjon, bahwa sarana perlindungan Hukum ada dua macam, yaitu Pertama, Perlindungan Hukum Preventif yaitu, subyek hukum diberikan kesempatan untuk mengajukan keberatan atau pendapatnya sebelum suaru keputusan pemerintah mendapat bentuk yang definitif. Tujuannya adalah mencegah terjadinya sengketa. Yang kedua Perlindungan Hukum Represif, Perlindungan hukum yang represif, yaitu bentuk perlindungan hukum dimana lebih ditujukan dalam penyelesaian sengketa. Penanganan perlindungan hukum bagi rakyat oleh pengadilan merupakan perlindungan hukum yang represif. (Budiartha, 2016: 138)

Sesuai peraturan OJK No.77/POJK.0112016 mengenai Layanan Pinjam Meminjam Uang Berbasis Teknologi lnformasi. Peraturan ini mengatur tentang teknologi keuangan, namun secara khusus hanya mengatur perjanjian jasa peminjaman yang tercantum dalam Pasal 18 sampai dengan 20. Sementara itu, berbeda dengan Peraturan Perbankan Indonesia 19/12/PBI 2017 tentang penyelenggaraan teknologi finansial, dalam peraturan difokuskan membahas keuangan yang bersifat general, karena dalam peraturan ini mengatur keseluruhan teknologi finansial dimana dijabarkan pada Pasal 3. Bank Indonesia pun telah menerbitkan regulasi mengenai Anggota Dewan Gubernur, peraturan ini hasil tindak lanjut dari ketentuan-Ketentuan Anggota Dewan Gubernur No. 19 memberikan informasi yang lebih terperinci tentang hal-hal, layanan dan metode pendaftaran serta ketentuan uji coba produk. Adanya kedua regulasi tersebut maka regulasi tersebut berguna memberikan perlindungan kepada konsumen berkaitan dengan data dana dan keperluan nasional berkaitan untuk mencegah pendanaan terorisme dan stabilitas sistem keuangan serta pencucian uang. Regulasi yang dibuat ini dapat menjadi payung hukum, dan financial technology serta harapannya tidak mengakibatkan persaingan ketat sesama pelaku usaha, sebab di dalam 2 regulasi ini dikhususkan untuk perusahaan berbadan hukum yang dapat menjadi penyedia teknologi finansial serta harus terlebih dahulu mendaftarkan diri.

Teknologi finansial dapat mengubah gaya hidup masyarakat dalam banyak hal, serta membantu kritisi negara, terutama sistem hukum yang ada di Indonesia, seperti membantu pengembangan perusahaan baru untuk meningkatkan kehidupan masyarakat, mengurangi pinjaman berbunga tinggi, dan mengembangkan undang-undang harus disertai kekhawatiran atau masalah tertentu. Contoh masalah besar di sektor teknologi finansial yaitu kebocoran data pribadi konsumen yang tidak dapat dilacak secara online. Menurut undang-undang, hal itu telah dikelola secara preventif dan beberapa aturan telah dirumuskan untuk menghukum berat tempat terjadinya tindakan tersebut. Dengan mencontohkan masalah tersebut, tentunya dapat dilakukan tindakan preventif yaitu setiap perusahaan financial technology wajib memberikan transparansi transaksi sebulan sekali yang biasa disebut Laporan Kegiatan Penanaman Modal (LKPM) ke Badan Kegiatan Penanaman Modal (BKPM).

\section{Upaya hukum yang dapat dilakukan oleh konsumen Teknologi Finansial jika data pribadi disalahgunakan oleh penyelenggara}

Upaya hukum adalah langkah-langkah hukum yang dilakukan oleh seseorang atau badan hukum untuk melawan putusan hakim atau putusan pengadilan karena dirasa tidak memenuhi rasa keadilan atau dirasa merugikan. Konsumen yang merasa dirugikan oleh penyelenggara teknologi finansial yang melakukan tindakan penyebaran data pribadi konsumen secara ilegal dapat dapat melakukan berbagai langkah hukum atas kerugian yang dideritanya, baik langkah hukum secara litigasi maupun non-litigasi. Meskipun pembahasan pada bab ini berfokus pada pembahasan Upaya Hukum yang terasosiasi pada 
proses hukum secara litigasi, namun mengingat terdapat kesalahpahaman masyarakat dalam penggunaan istilah upaya hukum dan langkah hukum, penelti berinisiatif untuk memasukkan pembahasan seputar langkah hukum juga setelah memberikan batasan pembeda antara keduanya. Hal ini penelti lakukan agar tujuan penelitian ini untuk memberi nilai manfaat baik teoritis maupun praktis dapat terwujud. Dengan adanya pembahasan langkah hukum dan upaya hukum diharapkan masyarakat yang membaca penelitian ini mendapatkan pemahaman dan wawasan (insight) terkait apa itu langkah hukum dan upaya hukum dan mengetahui kapan menggunakannya.

a. Langkah Hukum Non-Litigasi

Konsumen yang merasa dirugikan akibat tindakan penyebaran data pribadi oleh Penyelenggara Teknologi Finansial tanpa persetujuan dari konsumen lebih dahulu dapat melaporkan tindakan pelanggaran hukum tersebut kepada:

1) Kementerian Komunikasi dan Informatika Republik Indonesia

Pengguna dapat mengajukan keluhan kepada Kominfo Republik Indonesia dengan alasan penyelenggara sistem informasi elektronik yang tidak berhasil untuk memberikan perlindungan terhadap data pribadi pemakaiannya. Sejauh menyangkut tindakan hukum yaitu dapat berupa pengaduan, sehingga tidak perlu dibuktikan adanya unsur kerugian yang menyebabkan kebocoran data pribadi tersebut. Berketerkaitan hukuman dari pelanggaran ketentuan perlindungan data pribadi, terdapat ketentuan pada Pasal 36 Peraturan menteri kominfo 20/2016 yaitu teguran lisan dan tertulis, atas pemberhentian sementara aktivitas usaha dan/atau pengumuman melewati situs dalam jaringan (situs online);

2) Otoritas Jasa Keuangan (OJK).

Sanksi yang diberikan dapat berupa penutupan usaha jika tindakan tersebut dilakukan oleh Penyelenggara Teknologi Finansial yang legal. Pendekatan yang dilakukan akan berbeda jika penyelenggara teknologi finansial yang ilegal, OJK tidak dapat melakukan penegakan hukum karena seringkali domisili hukum penyelenggara teknologi finansial seperti ini berkedudukan di luar negeri sehingga pelaku tidak tunduk dan terikat pada hukum Indonesia karena berada di luar yurisdiksi Indonesia. Jika pelakunya adalah Penyelenggara Teknologi Finansial ilegal yang berdomisili di Indonesia maka pendekatan yang dilakukan dapat menggunakan proses penegakan hukum formal atau melalui jalur litigasi, baik dengan runtutan pidana maupun gugatan perdata.

b. Langkah Hukum Litigasi

Langkah-langkah hukum secara litigasi melalui lembaga peradilan formal adalah upaya dan langkah hukum terakhir (ultimum remedium) yang dapat diambil dalam penegakan hukum setelah upaya-upaya non-litigasi menemui jalan buntu. Penggunaan upaya hukum atau langkah-langkah hukum secara litigasi dapat dilakukan melalui ranah hukum pidana maupun hukum perdata. Langkah hukum pada ranah hukum pidana akan berakhir pada sanksi hukum berupa hukuman badan (penjara) atau hukuman pengganti (denda atau kurungan). Sedangkan upaya hukum atau langkah hukum pada ranah hukum perdata akan berakhir pada sanksi hukum berupa denda atau ganti rugi.

Pilihan penyelesaian hukum melalui ranah hukum pidana bisa menggunakan delik-delik pidana yang ada pada undang-undang organik maupun dalam Kitab Undang-Undang Hukum Pidana (KUHP) seperti delik penyebaran informasi elektronik secara ilegal, pencurian data elektronik, pengancaman melalui transaksi elektronik, bahkan mungkin menggunakan delik penipuan. Langkah-langkah hukum yang dapat dilakukan oleh konsumen yang merasa dirugikan dengan penggunaan data pribadi secara ilegal oleh pengelola teknologi finansial, adalah sebagai berikut:

1) Laporan Kepolisian di instansi kepolisian setempat. Bisa dilakukan di tingkat Kepolisian Sektor (Polsek) di wilayah sebuah kecamatan, Kepolisian Resor I Kota (Polresta) di wilayah sebuah kabupaten/kota, Kepolisian Daerah (Polda) di wilayah sebuah provinsi, atau di Markas Besar Kepolisian RI (Mabes Polri) untuk tingkat pusat atau nasional.

2) Pengadilan Negeri (untuk tingkat pertama)

3) Pengadilan Tinggi (untuk upaya hukum banding)

4) Mahkamah Agung (untuk upaya hukum kasasi dan peninjauan kembali)

Selain upaya atau langkah hukum pidana, konsumen yang merasa dirugikan oleh tindakan pengelola teknologi finansial dengan menggunakan data pribadi secara ilegal adalah melalui gugatan secara perdata. Gugatan perdata bertujuan untuk memulihkan (me-recovery) kerugian 
penggugat (konsumen) dengan sanksi denda atau ganti rugi yang dijatuhkan kepada tergugat (pengelola teknologi finansial) jika terbukti bersalah. Dalam hal ini gugatan yang diajukan adalah gugatan Perbuatan Melawan Hukum (PMH). Langkah-langkah hukum secara perdata yang dapat dilakukan oleh konsumen yang merasa dirugikan dengan penggunaan data pribadi secara ilegal oleh pengelola teknologi finansial, yaitu:

1) Mengajukan Gugatan Perbuatan melawan Hukum di Pengadilan Negeri setempat (untuk tingkat pertama)

2) Pengadilan Tinggi (untuk upaya hukum banding) Mahkamah Agung (untuk upaya hukum kasasi dan peninjauan kembali atau upaya hukum luar biasa lainnya)

\section{KESIMPULAN DAN SARAN}

\section{Kesimpulan}

Berdasarkan hasil dari pengumpulan dan pengolahan, maka penelti dapat menarik simpulan sebagai berikut

1) Perlindungan hukum mengenai data pribadi konsumen Teknologi Finansial diatur oleh Kominfo RI melalui Peraturan Menteri kominfo No. 20 Tahun 2016, oleh OJK melalui POJK No. 77 Tahun 2016, POJK No. 13 Tahun 2018 serta peraturan pelaksananya, yaitu Surat Edaran OJK. Data yang harus dilindungi yaitu:

a. Data pribadi perseorangan.

b. Data pribadi korporasi.

c. Data dan informasi non-publik yang bersifat material.

d. Data dan informasi terkait transaksi keuangan.

e. Data dan informasi terkait kontrak/perjanjian.

Perlindungan data pribadi adalah suatu bentuk privasi berupa hak pribadi yang mendapatjaminan oleh negara. Rancangan perlindungan data pribadi berarti bahwasannya perseorangan mempunyai hak untuk memutuskan atau tidak yakin atas berbagai data pribadi. Hak untuk melindungi data pribadi sangatlah berguna dan sebenarnya adalah bagian kunci dari kebebasan dan martabat pribadi. Terkait bisnis Teknologi Finansial, data pribadi konsumen Teknologi Finansial harus dilindungi. Jika data pribadi pengguna bocor, sanksi yang diatur dalam Peraturan Menteri Komunikasi dan Informatika Republik Indonesia dan POJK dapat diberlakukan ke pihak yang membeberkan individu konsumen tersebut.

2) Upaya hukum yang digunakan apabila dikemudian hari terjadi sengketa dan konsumen mengalami kerugian, korban penyalahgunaan data pribadi dapat melakukan Upaya Hukum dengan cara musyawarah serta pengaduan kepada Kemenkominfo atau OJK (non-litigasi) dan apabila tidak menyelesaikan sengketa konsumen dapat mengajukan gugatan perdata (litigasi) atas dasar Perbuatan Melanggar Hukum I PMH dan meminta ganti rugi.

\section{Saran}

Berdasarkansimpulan diatas maka dapat diajukan saran-saran sebagai berikut

1. Hukum Indonesia memberikan pemulihan dalam bentuk litigasi serta pengaduan tentang badan hukum yang data pribadinya telah disalahgunakan. Namun perlu diakui bahwa peraturan perundangundangan di Indonesia tentang data pribadi masih kurang memadai, misalnya mengingat sebagian besar pengontrol atau pemroses data adalah perusahaan asing, maka pelaksanaan upaya hukum masih belum sempurna. Oleh karena itu, pemerintah Indonesia diharapkan dapat segera menyelesaikan RUU Perlindungan Data Pribadi (RUU PDP) untuk melindungi kepentingan sah negara dan rakyat Indonesia, selain itu setiap orang harus melakukan tindakan pencegahan untuk melindungi data pribadinya.

2. Upaya perlindungan hukum bagi konsumen Teknologi Finansial dapat direalisasikan dengan bantuan seluruh pihak yang terkait. Konsumen harus

lebih proaktif dalam memahami hak dan risikonya, dan penyelenggara harus lebih terbuka dan meningkatkan kinerja agar hubungan hukum antara penyelenggara dan konsumen Teknologi Finansial dapat berfungsi secara maksimal, sebab dari kedua pihak bersama-sama memahami hak serta resikonya. Kemudian, kepercayaan konsumen mengenai penyelenggaraan akan bertambah banyak.

\section{DAFTAR PUSTAKA}

Ansori, M. (2019). Perkembangan dan Dampak Financial Technology (Fintech) Terhadap Industri Keuangan Syariah Di Jawa Tengah. Jurnal Studi Keislaman, Vol.5(1). 
Benuf, K., Mahmudah, S., \& Priyono, E. A. (2019). Perlindungan Hukum Terhadap Keamanan Data Konsumen Financial Technology di Indonesia. Refleksi Hukum Jurnal Ilmu Hukum, Vol.3(2).

Budiartha, I. N. P. (2016). Hukum Outsourcing: Konsep Alih Daya Bentuk Perlindungan dan Kepastian Hukum. Setara Press, Malang.

Chrismastianto, I. A. W. (2017). Analisis SWOT Implementasi Tekonologi Finansial terhadap Kualitas Layanan Perbankan di Indonesia. Jurnal Ekonomi Dan Bisnis, Vol.20(1).

Darmawan, R., Dewi, A. A. S. L., \& Karma, N. M. S. (2021). Perbandingan Kekuatan Hukum Alat Bukti Otentik Dan Perjanjian Bawah Tangan (Studi Kasus Perkara Nomor: 939/Pdt.G/2018/PN Dps). Jurnal Interpretasi Hukum, Vol.2(1).

Mahmudah, S., \& Priyono, E. A. (2019). Perlindungan Hukum Terhadap Keamanan Data Konsumen Financial Technology di Indonesia. Refleksi Hukum Jurnal Ilmu Hukum, Vol.3(2).

Margaretha, F. (2015). Dampak Electronic Banking Terhadap Kinerja Perbankan Indonesia. Jurnal Keuangan Dan Perbankan, Vol.19(3).

Pratama, G. Y., Suradi, \& Aminah. (2016). Perlindungan Hukum Terhadap Data Pribadi Pengguna Jasa Transportasi Online Dari Tindakan Penyalahgunaan Pihak Penyedia Jasa Berdasarkan Undang-Undang Nomor 8 Tahun 1999 Tentang Perlindungan Konsumen. Diponegoro Law Journal, Vol.5(3).

Puryanto, R. B., Budiartha, I. N. P., \& Ujianti, N. M. P. (2021). Perlindungan Hukum Bagi Pekerja dengan Perjanjian Kerja Tidak Tertulis Pada Perusahaan Pemberi Kerja. Jurnal Interpretasi Hukum, Vol.2(1).

Tongat. (2008). Dasar-dasar Hukum Pidana Indonesia dalam Perspektif Pembaharuan. PT. Raja Grafindo Persada, Malang. 